\title{
Czy warto dziś być niezadowolonym?
}

„Kultura Współczesna. Teoria. Interpretacja. Praktyka” 2 (64), 2010, 235 s.

Drugi numer kwartalnika „Kultura Współczesna” z 2010 roku został poświęcony zjawisku, które, choć jeszcze nie w pełni rozpoznane przez badaczy, w coraz większym stopniu określa emocjonalny klimat ponowoczesnego świata, z jednej strony stanowiąc wykładnik narastających pesymistycznych nastrojów społecznych, z drugiej zaś uzupełniając i urozmaicając duchowy krajobraz epoki. Autorzy omawiają bowiem zagadnienie tzw. kultur oporu, a zatem inicjatyw, procesów i działań, które w ujęciach teoretycznych lub praktycznych realizacjach przeciwstawiają się dominującym i ustabilizowanym rozwiązaniom politycznym i kulturowym, obnażając ich nieoczywistość i podając w wątpliwość nienaruszalność panującego układu sił.

Przy okazji rozważań dotyczących dysydenckich tradycji w kulturach słowiańskich, warto również przyjrzeć się współczesnym formom, mechanizmom i przejawom wyrażania niechęci do dominujących/obowiązujących reguł, wyznaczających zakres preferowanych czy choćby dopuszczalnych zachowań i z mocą autorytetu programujących współczesne modele egzystencji. Należy bowiem zadać sobie pytanie o kontynualny/heterogeniczny charakter najnowszych sygnałów narastania i demonstrowania potrzeby protestu i porównać ich rangę, rodzaj i zakres oddziaływania z dawniejszymi ruchami kontestacyjnymi. Część tekstów, zamieszczonych w omawianym numerze „Kultury Współczesnej”, bezpośrednio zresztą podejmuje próbę takiego porównania (np. Jana Sowy Co jest wywrotowe?; Piotra Juskowiaka Wspólnoty oporu w mieście postpolitycznym), akcentując przede wszystkim ich mniejszy w zestawieniu z poprzednikami „ładunek powagi” (Marek Krajewski używa nawet w tym kontekście określenia „rewolucja 
dla draki”) i większe (poza- czy ponadpolityczne) rozproszenie negowanych bolączek współczesności. Ewa Rewers we wprowadzeniu do zamieszczonych w czasopiśmie rozważań (Subwersyjny podmiot w ruchu) podkreśla, że:

Można spierać się o to, do jakiego stopnia określona tradycja krytyczna jest przestarzała, lecz nadal bierzemy pod uwagę aktualność i autentyczność krytycznego modelu interpretacji i wytwarzania rzeczywistości. Dostrzegamy zmienny w przejawach, lecz trwały potencjał subwersyjny w obrębie polityki, życia codziennego, teorii naukowych i sztuki, a zatem wewnątrz porządków symbolicznych wyspecjalizowanych w „wytwarzaniu” oporu (s. 8).

Autorka przypomina także o badawczym obowiązku rozpoznania owych, nadal aktualnych, przestrzeni subwersji i włączenia ich w eksploracyjne ramy najnowszej socjologii, politologii czy historii sztuki. O powinności takiej mówi też Rafał Drozdowski (Kultury oporu na jałowym biegu?), dopowiadając jednak, że współczesna humanistyka często nie dysponuje narzędziami zdolnymi do adekwatnego uchwycenia swoistości wielokształtnych manifestacji kulturowego protestu. Konieczność wypracowania takich narzędzi przyświeca również innym autorom, publikującym w kwartalniku i poszukującym właściwego języka opisu obserwowanych praktyk kontestacyjnych.

Zgodnie z tymi wstępnymi tezami, na zawartość numeru czasopisma składają się wypowiedzi socjologów, przedstawicieli culture studies, historyków sztuki i architektury czy medioznawców, próbujących rozpoznać wszelkie przejawy społecznego i indywidualnego niezadowolenia, które skutkują konkretnymi działaniami, stanowiącymi wyraz frustracji i w rezultacie aktywnie dążącymi do wdrożenia w życie propozycji odmiennych. Autorzy kolejnych artykułów analizują zachowania, reakcje i zabiegi ludzi źle zadomowionych w świecie, nieznajdujących dla siebie miejsca w przestrzeni ekonomicznej, społecznej, politycznej czy kulturowej, pokrzywdzonych przez systemowe uwarunkowania lub niegodzących się na monopolistyczne aspiracje korporacyjnej hegemonii. Kwestionują więc narzucane przez oficjalnie ,zatwierdzone” ideologie przeświadczenie, że żyjemy „,w najlepszym z możliwych światów" i przypominają o istnieniu Innych, tych, którzy pozostają poza granicami pozornie każdemu dzisiaj zagwarantowanej promesse de bonheur. Nie zanikły wszak przyczyny protestu, nie zniknęły 
obszary wykluczenia, nadal istnieją miejskie getta i stale rodzą się nowe niebezpieczeństwa, zagrażające indywidualnej i wspólnotowej tożsamości, niepozwalające na pełną i satysfakcjonującą samorealizację. Przeciwko nim powstają rozmaicie skonfigurowane, pozbawione formalnego umocowania, często płynne i z reguły trudno uchwytne ruchy kontestacyjne. Ich enklawowy charakter powoduje, że nie odgrywają one wiodącej roli w przekształcaniu bądź demontowaniu dominującego porządku (zarówno politycznego czy społecznego, jak i kulturowego), często ograniczając się do lokalnych i inspirowanych okazjonalnymi przyczynami inicjatyw, bliższych z reguły artystycznym happeningom niż realnym zabiegom, prowadzącym do przemiany rzeczywistości.

Wiele $\mathrm{z}$ tych ruchów obiera taktykę rozsadzania systemu od wewnątrz, wpisując się w ramy wyznaczone przez mainstreamowe tendencje, redukujące „przestrzeń akceptowanego" do narzucania określonych mód i wzorców estetycznych i egzystencjalnych, ale pozostawiające też duży margines swobody dla nieoficjalnych czy oddolnych kulturowych propozycji, w ostatecznym rozrachunku wzbogacających jedynie asortyment dostępnych na rynku produktów. Jak pisze Jan Sowa w artykule Co jest wywrotowe?: „Historia pokazała, jak doskonale kapitalizm asymiluje wszelkie próby podważania go i w jak perwersyjny sposób potrafi tak zrekonfigurować pole idei, aby to, co było w niego wymierzone, stało się kolejną procedurą umacniania jego władzy" (s. 13). Wtóruje mu Rafał Drozdowski (Kultury oporu na jałowym biegu?), który twierdzi, że ,większość praktyk kulturowych, które wchodzą w spór czy wręcz w otwarty konflikt z kulturą dominującą i które pragną być postrzegane jako jej alternatywa, niebezpiecznie łatwo konwencjonalizuje się, zrastając się w rezultacie z kulturowym mainstreamem" (s. 27). Podobne konstatacje, powracające we wszystkich niemal tekstach, pokazują, jak trudno w warunkach panującej dowolności i szczególnej mocy absorpcyjnej, którą operują maszyneria medialna i wolny rynek, wypracować autentyczne i efektywne narzędzia oporu. Przeświadczenie, że wszyscy z konieczności uczestniczą w dominujących reprezentacjach kulturowych, oznacza, że opuszczenie ich granic jest złudne czy przynajmniej pozorne i nie daje w praktyce szansy na rzeczywistą zmianę sytuacji. Przemysł kulturowy bowiem dysponuje narzędziami umożliwiającymi oswojenie czy wchłonięcie wszelkich kontestacyjnych propozycji, pod warunkiem jednak, że odnajdzie w nich szansę powiększenia zysków i otwarcia swej 
oferty na nowe kręgi odbiorców. Zdrada ideałów, spowodowana niemal nieuchronnie przez uniwersalny i bezwarunkowy de facto wymiar tych zdolności absorpcyjnych, a stanowiąca konsekwencję globalnych procesów urynkowienia wszystkiego, co wkracza w przestrzeń aktywności skomercjalizowanej kultury, budzi zainteresowanie i prowokuje do zastanowienia się nad (nie)możliwością funkcjonowania poza ramami wyznaczonymi przez dominujące dyskursy. Otwiera to, toczoną w części artykułów (m.in. we wspomnianych już wypowiedziach Ewy Rewers, Jana Sowy, Rafała Drozdowskiego), debatę na temat relacji wnętrza i zewnętrza, za pomocą której owe dyskursy wyznaczają swe granice i definiują repertuar dystrybuowanych w tych granicach środków, sposobów i metod reprezentacji i organizowania rzeczywistości.

W takiej sytuacji radykalnie kurczy się obszar potencjalnej zewnętrzności, do minimum zredukowane zostają obszary odmowy podporządkowania się wymogom panującego systemu. Odrzucenie uczestnictwa w mainstreamowych trendach (np. rezygnacja z posiadania telewizora, omijanie galerii handlowych, bojkot globalnych marek) owocuje co prawda zaktywizowaniem alternatywnych praktyk kulturowych, bazujących na zaproponowaniu paralelnych preferencji i modeli społecznych czy estetycznych, ale nie prowadzi do autentycznego odwrócenia ról, które, jak zdają się potwierdzać poszczególne artykuły, zostały już na stałe rozpisane i nie wymagają dalszych renegocjacji. W efekcie kolejni autorzy koncentrują uwagę na tych formach oporu (nie tylko zresztą kulturowego), które nie zyskują powszechnej aprobaty i nie są najczęściej zbyt szeroko zakrojone, ich zasięg i zakres zachowują zatem wymiar lokalny bądź w sensie geograficznym, bądź z punktu widzenia liczby zaangażowanych uczestników akcji protestacyjnej (np. manifestacje ekologów czy alterglobalistów, twórczość graficiarzy, polityczne i antykorporacyjne interwencje hakerów ${ }^{1}$ lub pikiety przeciwników zmian dokonywanych w codziennym otoczeniu), choć jednocześnie, na co zwraca uwagę Jan Sowa (s. 14), operują bardzo restrykcyjnymi kryteriami rekrutacji członków i autorytarnie limitowanym podziałem na „swoich i obcych”.

Zamieszczone w kwartalniku teksty rozpatrują różnorodne i heterogeniczne przejawy oporu kulturowego - od spektakularnych akcji,

1 Tym tematem zajmuje się Ewa Wójtowiczw artykule Wiki-obywatelskie niepostuszeństwo. Alternatywne oblicze sztuki w kulturze cyfrowej (s. 100-114). 
odpowiednio nagłaśnianych w mediach (a zatem automatycznie włączanych w przestrzeń mainstreamu), po sygnały oporu „rozproszonego”, uprawianego indywidualnie lub w nielicznych ,grupach wsparcia”, często „W zaciszu domowym” i bez potrzeby publicznej manifestacji. Zajmujący się rolą takich inicjatyw (np. majsterkowanie i korzystanie $\mathrm{z}$ tradycyjnych narzędzi, własnoręczne pieczenie chleba czy przygotowywanie posiłków z nieprzetworzonych produktów) Marek Krajewski (w artykule Dyskretna niezgoda. Opór i kultura materialna) podkreśla ich „wywrotowy” potencjał, polegający przede wszystkim na podkopywaniu unifikacyjnych procesów komercjalizacji, która, zmuszając do korzystania ze standardowej oferty rynku, utrudnia zarazem wyodrębnienie jednostki ludzkiej z tłumu.

Celem operacji kontestacyjnych opisywanych w czasopiśmie pozostaje więc zawłaszczanie większości praktyk społecznych przez wszechobecny konsumpcjonizm. Część autorów dowodzi jednak obosieczności poszczególnych „znaków rozpoznawczych” ponowoczesnej globalnej komercjalizacji, z jednej strony utwierdzających, z drugiej strony zaś podważających jej własne podstawowe założenia. Maja Brzozowska-Brywczyńska w artykule (Przeciw)słodkie: subwersyjny potencjat estetyki (anty)cuteness przypomina na przykład, że:

Niezależnie od potencjalnej konwertowalności instrumentarium kulturowego oporu w towary-znaki na konsumpcyjnym rynku, która do pewnego stopnia dyskredytuje te formy subwersji, i niezależnie od oceny domniemanego stopnia ich autentyczności, opór lifestylowy może dawać jednostkom - po prostu - poczucie sprawczości niewprzęgnięte w nieznośny dydaktyzm cechujący niejednokrotnie całościowe alternatywne projekty porządkowania rzeczywistości społecznej (s. 116).

Badaczka dowodzi tu, opisując fenomen Hello Kitty i japońskiej kultury kawaii, że niektóre kiczowe reprezentacje, choć wytworzone i eksploatowane przez rynek, mogą również, oczywiście odpowiednio wykorzystane i zinterpretowane, służyć zakwestionowaniu obowiązujących powszechnie zadań stawianych przed członkami społeczeństwa. W tym konkretnym przypadku mowa o dowartościowaniu infantylności, czego sygnały Brzozowska-Brywczyńska odnajduje w estetyce cuteness i wypływającym z niej tzw. „upluszowieniu” rzeczywistości. Do podobnych wniosków dochodzi też Agata Skórzyńska w wypowiedzi Subwersje miejskie. Niewyraźne kultury oporu, ukazując rolę postmodernistycznej gry z konwencjami kultury 
popularnej w produkcji tzw. artivistów, czyli, najogólniej mówiąc, przedstawicieli nieoficjalnej sztuki miejskiej.

Należy w tym miejscu podkreślić, że osobnym i powracającym w wielu tekstach wątkiem rozważań pozostaje kwestia urbanistycznego charakteru kulturowych przejawów oporu. Ingerencja w przestrzeń miejską, niekontrolowana przez instytucjonalne projekty i zarządzenia, oznacza bowiem najbardziej być może wyrazisty przykład niezgody na monopol panującego porządku. O niechęci do zestandaryzowanych rozwiązań współczesnego urbanizmu piszą przede wszystkim znawcy architektury: Marcin Adamczak w artykule Architektura i przypadek. „Aleatoryczna” budowla jako forma oporu wobec constans racjonalnego planowania oraz Michał Podgórski, autor tekstu Negacja negacji, czyli opór przeciw antymaterii. Przeglądu dzisiejszych praktyk prowadzących do przekształcenia społecznej stratyfikacji miasta dokonuje zaś Piotr Juskowiak (Wspólnoty oporu $w$ mieście postpolitycznym), eksponując rolę rewolucyjnej multitude (wielości), której przeciwstawia podtrzymującą roszczenia władzy, globalną metropolis.

Dwa zamieszczone w kwartalniku teksty: Game farming - ponowoczesna forma praco-zabawy Radosława Bomby oraz Nowe, wspaniałe, inteligentne otoczenie. O szansach i zagrożeniach zwiazanych z Ambient Intelligence Kajetana Mojsaka dotykają problematyki współczesnej kontestacji z nieco innego punktu widzenia. Prezentują bowiem fenomeny, które - jeszcze - nie stały się przedmiotem mniej lub bardziej zorganizowanego oporu. W pierwszym przypadku mowa o handlu wirtualnymi „towarami”, owocującym, zwłaszcza w Chinach, nowymi formami wyzysku pracowników. Artykuł Mojsaka referuje natomiast dyskusję, która toczy się wokół futurologicznych (ale realnych) projektów zainstalowania tzw. inteligentnego otoczenia, a zatem wytworzenia elektronicznych udogodnień w dziedzinie organizacji życia codziennego, dostosowanych do wymagań indywidualnego konsumenta. Niepokój budzi tu przede wszystkim możliwość dysponowania i manipulacji danymi osobowymi i wypływająca stąd obawa o utratę prywatności i całkowite podporządkowanie wszystkich sfer życia anonimowym administratorom sieci.

Zamieszczone w czasopiśmie artykuły opisują zatem kultury oporu w rozmaitych przekrojach i aspektach, rozpatrując je z różnych stron. Pokazują, jak nieustannie, wewnątrz (pozornie!) ustabilizowanego układu sił, definiowanego przez dominację instytucjonalnie usankcjonowanych norm, 
operują „podskórne” ruchy kontestacyjne, podkopujące nienaruszalność panującego porządku i wydobywające na jaw jego „słabe punkty” i mankamenty. Podczas lektury części tekstów uderza ich lewicowe, ,antykapitalistyczne" przesłanie, odzwierciedlające wyraziście zarysowane poglądy autorów, a zatem wpisujące się w projekt humanistyki zaangażowanej. Niejednokrotnie artykuły te sygnalizują oczekiwanie na radykalną zmianę, która wypływa z coraz wyraźniejszej dziś świadomości kryzysu demokracji liberalnej, coraz częściej kwestionowanej, ale nadal uzurpującej sobie prawo do decydowania o aprobowanych modelach zachowań codziennych, praktyk społecznych i sposobów odczytywania tekstów kultury oraz reakcji na współczesny kształt cywilizacji. Gdy jednak rodzi się poczucie zawodności i niepełnej miarodajności tych modeli, nie tylko nieułatwiających, ale wręcz utrudniających wypracowanie dla siebie miejsca w postmodernistycznym świecie, zaczyna się poszukiwanie nowych - budowanych na odmiennych, często subwersyjnych, zasadach - strategii oswajania rzeczywistości.

Anna Gawarecka 